\title{
Effects of background fertilization followed by co-application of two kinds of bacteria on soil nutrient content and rice yield in Northeast China
}

\author{
Tao Sun ${ }^{1,2}$, Yuyingnan $\mathrm{Liu}^{4}$, Shuang $\mathrm{Wu}^{2}$, Jizhou Zhang ${ }^{3}$, Bin $\mathrm{Qu}^{4 *}$, Jinggang $\mathrm{Xu}^{1^{*}}$ \\ (1. College of Resources and Environment, Northeast Agricultural University, Harbin 150030, China; \\ 2. Heilongjiang Provincial Ecological Meteorological Center, Harbin 150030, China; \\ 3. Institute of Natural Resources and Ecology, Heilongjiang Academy of Sciences, Harbin 150040, China; \\ 4. College of Engineering, Northeast Agriculture University, Harbin 150030, China)
}

\begin{abstract}
With the improvement of living standards, people pay more and more attention to the quality and safety of rice. Microbial agents are favored by the public because they can activate the nutrient supply in the soil, and reduce the residue and application amount of chemical fertilizers and pesticides. Based on the conventional fertilization in the field, Bacillus mucilaginosus and Aspergillus niger were applied, Bacillus mucilaginosus was inoculated at four levels in the paddy soil in the cold region of Heilongjiang Province of China. The effects of different proportions of Bacillus mucilaginosus and Aspergillus niger on the number of soil microorganisms, enzyme activity, microbial biomass, soil biochemical intensity, soil nutrient content, plant nutrient content and yield were studied, and the effects on the plant nutrient content of rice and the nutrient dynamics were discussed. The results showed that a 2.62\%-21.20\% higher yield of rice obtained from co-application treatments compared with that of the control-blank treatment. Furthermore, the highest yield obtained $\left(10736 \pm 65 \mathrm{~kg} / \mathrm{hm}{ }^{2}\right)$ suggested that the optimized values for the two bacteria applied were $120 \times 10^{11} \mathrm{CFU} / \mathrm{hm}^{2}$ for Bacillus mucilaginosus and $15 \times 10^{11} \mathrm{CFU} / \mathrm{hm}^{2}$ for Aspergillus niger. Bacillus mucilaginosus can decompose minerals in soil, dissolve potassium and silicon, decompose apatite and release phosphorus into soil. Aspergillus niger can transform the phosphate which cannot be absorbed by plants into soluble phosphate which can be directly absorbed by plants by producing non-volatile acids. In particular, Bacillus mucilaginosus and Aspergillus niger have synergistic effect, and their combined application effect is greater than that of two bacteria alone. Co-application promoted the release of soil soluble silicon, and then increased the silicon content of plants. At the same time, soil microorganism, microbial biomass, enzyme activity and biochemical activity all increased significantly. This study provides an effective way to reduce the amount of chemical fertilizer applied in rice production in cold regions of China.
\end{abstract}

Keywords: microbial inoculants, microbial fertilizer, rice, co-application, Bacillus mucilaginosus, Aspergillus niger, nutrients DOI: $10.25165 /$ j.ijabe.20201302.4863

Citation: Sun T, Liu Y Y N, Wu S, Zhang J Z, Qu B, Xu J G. Effects of background fertilization followed by co-application of two kinds of bacteria on soil nutrient content and rice yield in Northeast China. Int J Agric \& Biol Eng, 2020; 13(2): 154-162.

\section{Introduction}

During the "Twelfth Five-Year Plan" period, Chinese agricultural sector clearly defined the basic goal of "One Regulatory, Two Reduction and Three Basic", and actively built a supporting green output increase model around the target agricultural sectors at all levels ${ }^{[1-4]}$. Among them, the goal of reducing chemical fertilizer application is to achieve zero growth of chemical fertilizer application by 2020, improve the nutrient utilization rate of food production, soil fertility and comprehensive

\section{Received date: 2019-09-28 Accepted date: 2020-02-12}

Biographies: Tao Sun, PhD, Engineer, research interests: agroecological environment, Email: yikehan@neau.edu.cn; Yuyingnan Liu, Master candidate, research interests: agricultural biological environmental and energy engineering, Email: tomtom12138@outlook.com; Shuang Wu, Master, Engineer, research interests: ecology, Email: 252600976@qq.com; Jizhou Zhang, PhD Candidate, Associate Professor, research interests: soil environment, Email: jizhou1980229@126.com.

*Corresponding author: Bin Qu, PhD, Associate Professor, research interests: agricultural biological environment and energy engineering. College of Engineering, Northeast Agriculture University, Harbin 150030, China. Tel: +86-451-55191670, Email: qubin@neau.edu.cn; Jinggang Xu, PhD, Professor, PhD Supervisor, research interests: soil fertility and agricultural environmental protection. College of Resources and Environment, Northeast Agricultural University, Harbin 150030, China. Email: xujinggang@neau.edu.cn. benefits, and achieve green and sustainable food production development of reducing weight and increasing efficiency in food production, increasing fertility and "storing grain on the ground". More than half of the world's population is dependent on rice (Oryza sativa L.), which is a major global crop $^{[5]}$. The total rice-cropped area in the world and global rice production are 163.25 million $\mathrm{hm}^{2}$ and 740.96 million $\mathrm{t}$, respectively ${ }^{[6]}$. The yield of rice is significantly dependent on silicon $(\mathrm{Si})$ in the soil. The growth and development of rice can be promoted by the absorption of $\mathrm{Si}$; however, because of its existing form, most of the $\mathrm{Si}$ in soil cannot be directly absorbed and utilized. Furthermore, the amount of available $\mathrm{Si}$ in soil decreases during long-term planting due to continuous consumption by rice plants. Although conventional chemical fertilizers are mainly used in rice production in northeast China, unfortunately, most of them do not contain Si. Apart from Si, phosphorus (P) is also an essential element for plant and animal life. The utilization of $\mathrm{P}$ is heavily relied on in agriculture, but current practices are inefficient. Approximately $80 \%-90 \%$ of added $\mathrm{P}$ fertilizers become unavailable to plants in the first year due to run-off or adsorption by soil minerals ${ }^{[7-11]}$. Furthermore, the excessive use of chemical fertilizers contributes toward soil, air and water pollution ${ }^{[12]}$. Therefore, the gradual replacement of chemical fertilizers with biofertilizers and beneficial microorganisms is vital. 
Microbial fertilizer refers to a specific type of product containing live microorganisms, which can be used in agricultural production to obtain specific fertilizer effects ${ }^{[13]}$. In this effect, live microorganisms play a key role ${ }^{[14-16]}$. In 1885 , Berthelot's basin experiments showed that microorganisms could convert nitrogen from the air into soil nitrogen that could be absorbed by plants through nitrogen fixation ${ }^{[17]}$. In 1895, the German scientist Noble developed the world's earliest microbial fertilizer "Nitragin" rhizobium inoculum patent product ${ }^{[18]}$, and since then, the microbial fertilizer has gradually come into people's attention. In the 1930s, the research on microbial fertilizer in China was just beginning. Zhang ${ }^{[17]}$ took the lead in researching the inoculation technology of soybean rhizobia, and isolated 130 nitrogen-fixation bacteria strains from soil samples in northeast China ${ }^{[19]}$, which increased the average yield of soybean by more than $10 \%^{[20]}$. In the 1960s, "5406" antibiotic fertilizer and nitrogen-fixing blue-green algal fertilizer made from actinomycetes were popularized and applied in $\mathrm{China}^{[21]}$. In the 1990 s, Liu et al. ${ }^{[22]}$ developed a biological potassium fertilizer with Bacillus circulans as an effective strain ${ }^{[23]}$. The microbial fertilizer that appeared during this period is characterized by a single vegetative bacterium, and the content and effectiveness of major nutrient elements in the soil are mainly improved by utilizing microbial characteristics ${ }^{[24]}$.

Microbial fertilizer also activates the soil nutrient supply, improve soil fertility, crop yield and quality, reduce the residues and dosages of chemical fertilizers, and protect the soil environment ${ }^{[25]}$. Insoluble Si and other elements in the soil can be transformed by Bacillus mucilaginosus (B. mucilaginosus) into available forms for plants to absorb and utilize. B. mucilaginosus could also produce hormones that promote plant growth and could also improve the $\mathrm{P}$ and potassium $(\mathrm{K})$ nutritional status of the soil, which have beneficial effects on the growth of plants. Several soil fungi, particularly those belonging to Aspergillus niger (A. niger), possess the ability to bring insoluble $\mathrm{P}$ into soluble forms by secreting low molecular weight organic acids, leading to improvements in plant absorption and utilization of $\mathrm{P}^{[26-28]}$. The currently available research on biofertilizers has mainly focused on the application of single bacteria. Few studies have discussed the effect of co-applications of B. mucilaginosus and A. niger on the nutrient availability and utilization rates of paddy soil ecosystems, e.g., the changes in nutrient content and availability after interactions between B. mucilaginosus and A. niger take place.

In this study, Chinese paddy soil in the cold region of Heilongjiang Province, China, was investigated. Heilongjiang Province is the primary area of rice production in China and shoulders the heavy responsibility of $1 / 3$ of China's total rice production $^{[29]}$. B. mucilaginosus (silicate bacteria) and A. niger (phosphate-solubilizing bacteria) were studied based on fertilization conventions, and their effects on rice nutrient contents and soil nutrient dynamics were investigated. The objectives of this study were to identify the optimal proportions of microbial inoculants suitable for local use, to provide an effective way to reduce the amount of chemical fertilizers applied in rice production and to provide guidance for the research of $\mathrm{Si}$ and $\mathrm{P}$ availability in the rice-soil ecosystem.

\section{Materials and methods}

\subsection{Plant material}

The rice genotype used in the experiment was Daohuaxiang II. The growing period and accumulated temperature for Daohuaxiang
II were $147 \mathrm{~d}$ and $2850^{\circ} \mathrm{C}$, respectively. Daohuaxiang II is a late-maturing rice variety, which was planted on April 15 and transplanted on May 16.

The microbial inoculants used were $B$. mucilaginosus $\left(-2 \times 10^{8} \mathrm{CFU} / \mathrm{g}\right.$ soil) and A. niger $\left(-1 \times 10^{8} \mathrm{CFU} / \mathrm{g}\right.$ soil $)$, which were selected from the Soil Environment Research Institute of Northeast Agricultural University. B. mucilaginosus exhibited properties of K-dissolution, Si-dissolution, $\mathrm{P}$-solubilization and $\mathrm{N}$-fixation, while $A$. niger had the ability of P-solubilization.

Traditional fertilizer was applied as background fertilization, which included di-ammonium phosphate ( $\left.\mathrm{N} 18 \%, \mathrm{P}_{2} \mathrm{O}_{5} 46 \%\right)$, urea ( $\mathrm{N} 46 \%)$, calcium superphosphate $\left(\mathrm{P}_{2} \mathrm{O}_{5} 13.5 \%\right)$, and potassium chloride $\left(\mathrm{K}_{2} \mathrm{O} 60 \%\right)$.

\subsection{Experimental design}

B. mucilaginosus and A. niger were applied in this experiment, with traditional fertilizer serve as control. After transplanting, before turning green tiller, the microorganisms were applied in solid granule media to $0-5 \mathrm{~cm}$ soil according to different testing proportions. B. mucilaginosus was inoculated at four levels $0 \mathrm{CFU} / \mathrm{hm}^{2}$ (B0), $60 \times 10^{11} \mathrm{CFU} / \mathrm{hm}^{2}$ (B1), $120 \times 10^{11} \mathrm{CFU} / \mathrm{hm}^{2}$ (B2) and $240 \times 10^{11} \mathrm{CFU} / \mathrm{hm}^{2}(\mathrm{~B} 3)$. A. niger was set up at three levels: $0 \mathrm{CFU} / \mathrm{hm}^{2}$ (A0), $7.5 \times 10^{11} \mathrm{CFU} \cdot \mathrm{hm}^{-2}$ (A1) and $15 \times 10^{11} \mathrm{CFU} / \mathrm{hm}^{2}$ (A2). In general, 12 treatments (B0A0, B0A1, B0A2, B1A0, $\mathrm{B} 1 \mathrm{~A} 1, \mathrm{~B} 1 \mathrm{~A} 2, \mathrm{~B} 2 \mathrm{~A} 0, \mathrm{~B} 2 \mathrm{~A} 1, \mathrm{~B} 2 \mathrm{~A} 2$, B3A0, B2A1 and B3A2) with three replicates, i.e., a total of 36 test plots, were included in the experiment, as shown in Table 1. The area for each plot was $66.7 \mathrm{~m}^{2}$, and each plot was surrounded by a $45-\mathrm{cm}$-high plastic sheet with $10 \mathrm{~cm}$ buried in soil. The plots also had a single irrigation and single drainage system. The field management practices used in the experiment followed the local field management practices of the area.

Table 1 Evaluation plan of experimental treatments in field

\begin{tabular}{ccc}
\hline Treatment & $\begin{array}{c}\text { B. mucilaginosus } \\
/ 10^{11} \mathrm{CFU}^{-2} \mathrm{hm}^{-2}\end{array}$ & $\begin{array}{c}\text { A. niger } \\
/ 10^{11} \mathrm{CFU} \cdot \mathrm{hm}^{-2}\end{array}$ \\
\hline B0A0 (control-blank) & 0 & 0 \\
B0A1 & 60 & 0 \\
B0A2 & 120 & 0 \\
B0A3 & 240 & 0 \\
B1A0 & 0 & 7.5 \\
B1A1 & 60 & 7.5 \\
B1A2 & 120 & 7.5 \\
B1A3 & 240 & 7.5 \\
B2A0 & 0 & 15 \\
B2A1 & 60 & 15 \\
B2A2 & 120 & 15 \\
B2A3 & 240 & 15 \\
\hline
\end{tabular}

\subsection{Field experiment}

The experiment was carried out between 2014 and 2015 in Auspicious agricultural planting cooperative, Yagou town of Acheng district, Harbin city, which is located in southern Heilongiang Province $\left(45^{\circ} 31^{\prime} \mathrm{N}, 126^{\circ} 25^{\prime} \mathrm{E}\right)$. The location has a continental monsoon climate in the cold temperate zone. The annual mean temperature, sunshine, accumulated active temperature, average precipitation and frost-free days are $3.4^{\circ} \mathrm{C}$, $24421 \mathrm{~h}, 2946^{\circ} \mathrm{C}, 569.1 \mathrm{~mm}$ and $162 \mathrm{~d}$, respectively. The soil was a white pulp-type paddy soil on which rice had been grown for over 20 years. The soil fertility was medium, and the soil quality was uniform. The basic fertility of the tested soil is listed in Table 2 . 
Table 2 Basic fertility properties of the tested soil

\begin{tabular}{|c|c|c|c|c|c|c|c|}
\hline $\begin{array}{c}\text { Organic matter } \\
/ \mathrm{g} \cdot \mathrm{kg}^{-1}\end{array}$ & $\begin{array}{l}\text { Total N } \\
/ \mathrm{g} \cdot \mathrm{kg}^{-1}\end{array}$ & $\begin{array}{l}\text { Total P } \\
/ \mathrm{g} \cdot \mathrm{kg}^{-1}\end{array}$ & $\begin{array}{c}\text { Alkali-hydrolyzable } \mathrm{N} \\
\qquad / \mathrm{mg} \cdot \mathrm{kg}^{-1}\end{array}$ & $\begin{array}{l}\text { Available P } \\
/ \mathrm{mg} \cdot \mathrm{kg}^{-1}\end{array}$ & $\begin{array}{l}\text { Available K } \\
\text { /mg } \mathrm{kg}^{-1}\end{array}$ & $\begin{array}{l}\text { Available Si } \\
/ \mathrm{mg} \cdot \mathrm{kg}^{-1}\end{array}$ & $\mathrm{PH}$ \\
\hline 21.65 & 1.52 & 0.9 & 125.1 & 24.2 & 139.0 & 242.4 & 6.1 \\
\hline
\end{tabular}

\subsection{Sample analyses}

The quantity of soil microorganisms was determined by the dilution plate counting method ${ }^{[30]}$. The soil microbial biomass carbon and nitrogen were determined by the chloroform fumigation and extraction method ${ }^{[31]}$. The activities of urease, invertase and acid phosphatase in the soil were determined to be similar to that reported by Guan et al. ${ }^{[32]}$. The biochemical activity intensity was measured according to methods reported in the current literature ${ }^{[30]}$.

The total concentrations of $\mathrm{Si}, \mathrm{N}, \mathrm{P}$ and $\mathrm{K}$ in the rice plants were measured after the samples were crushed ${ }^{[33]}$. The concentrations of $\mathrm{Si}$ in the rice plants were determined by silicon molybdenum blue colorimetry. The total $\mathrm{N}$ in the rice plant was determined by the Nesslerization method. The total $\mathrm{P}$ in the rice plant was determined by the vanadium molybdate yellow colorimetric method.

The theoretical rice yield was calculated as follows: 5 points along the diagonal line of each plot were selected. For each point, 21 lines were subsequently applied, and the space between the lines was measured. The distance between each rice plant was further calculated, and the number of hills per square meter was calculated. Then, 20 hills were selected to calculate the number of effective leaves per $\mathrm{hm}^{2}$. Finally, the number of grains per leaf and the ripening rate in 2-3 hills were investigated. The detailed calculation is shown below.

Theoretical yield $(\mathrm{kg})=$ effective spikes $\left(\right.$ spike) per $\mathrm{hm}^{2} \times$ number of grains per spike (grain) $\times$ ripening rate $(\%) \times$ thousand-grain weight $(\mathrm{g}) \times 10^{-6} \times 85 \%$.

\subsection{Data analyses}

The experimental data were statistically analyzed by SPSS 19.0 software and Excel 2007. The differences between treatments were analyzed by Duncan at a 0.05 confidence level.

\section{Results and discussion}

\subsection{Effects of $B$. mucilaginosus and $A$. niger on soil microorganisms.}

Bacteria, fungi and actinomycetes are the main groups of soil microorganisms that play an important role in soil energy conversion, nutrient cycling and humus formation ${ }^{[34]}$. In general, the amount of soil microorganisms showed significant changes with the applications of B. mucilaginosus and A. niger, as shown in Table 3. The number of bacteria in the soil increased with the application of both B. mucilaginosus and Aspergillus niger. For the treatments with single applications of $B$. mucilaginosus, the number of soil bacteria increased steadily with increasing amounts of $B$. mucilaginosus, whose maximum was $14.0 \pm 2.0 \%\left(10^{7} \mathrm{CFU} / \mathrm{g}\right)$ for B3A0. This trend is similar to that reported in the literature ${ }^{[35]}$. For the treatments with a single application of A. niger, the maximum was $14.6 \pm 1.0 \%\left(10^{7} \mathrm{CFU} / \mathrm{g}\right)$ for B0A2. This is attributed to the fact that $A$. niger, being a phosphate-solubilizing bacterium, might activate the phosphorus in the soil, resulting in increased organic phosphorus concentrations and consequently increased fungal concentration of the soil ${ }^{[36]}$. However, for the treatments with co-applications of B. mucilaginosus and A. niger, the amount of soil bacteria was significantly higher than that for treatments with single applications by $6.67 \%-82.25 \%$. Note that this figure was also $167.4 \%$ higher than that of the control-blank treatment
(B0A0). The maximum number of bacteria was $19.2 \pm 1.0 \%$ $\left(10^{7} \mathrm{CFU} / \mathrm{g}\right)$ for B2A2.

Table 3 Effects of $B$. mucilaginosus and $A$. niger on soil microorganisms

\begin{tabular}{cccc}
\hline Treatment & $\begin{array}{c}\text { Bacteria } \\
\left(10^{7} \mathrm{CFU} \cdot \mathrm{g}^{-1}\right)\end{array}$ & $\begin{array}{c}\text { Fungi } \\
\left(10^{2} \mathrm{CFU} \cdot \mathrm{g}^{-1}\right)\end{array}$ & $\begin{array}{c}\text { Actinomycetes } \\
\left(10^{5} \mathrm{CFU} \cdot \mathrm{g}^{-1}\right)\end{array}$ \\
\hline B0A0 & $7.18 \pm 0.62 \mathrm{e}$ & $49.3 \pm 1.1 \mathrm{ef}$ & $34.9 \pm 1.1 \mathrm{e}$ \\
B1A0 & $10.5 \pm 0.4 \mathrm{c}$ & $50.0 \pm 1.0 \mathrm{ef}$ & $39.4 \pm 0.8 \mathrm{c}$ \\
B2A0 & $13.0 \pm 0.2 \mathrm{~b}$ & $47.0 \pm 0.8 \mathrm{f}$ & $44.7 \pm 0.3 \mathrm{~b}$ \\
B3A0 & $14.0 \pm 2.0 \mathrm{~b}$ & $48.8 \pm 1.5 \mathrm{f}$ & $48.5 \pm 0.9 \mathrm{a}$ \\
B0A1 & $10.6 \pm 0.7 \mathrm{c}$ & $57.7 \pm 0.8 \mathrm{~cd}$ & $35.1 \pm 1.3 \mathrm{e}$ \\
B1A1 & $10.7 \pm 0.8 \mathrm{c}$ & $55.3 \pm 1.0 \mathrm{~d}$ & $39.1 \pm 0.8 \mathrm{c}$ \\
B2A1 & $14.7 \pm 0.8 \mathrm{~b}$ & $56.7 \pm 0.5 \mathrm{~cd}$ & $44.5 \pm 0.8 \mathrm{~b}$ \\
B3A1 & $18.0 \pm 0.7 \mathrm{a}$ & $62.7 \pm 1.8 \mathrm{c}$ & $48.6 \pm 0.7 \mathrm{a}$ \\
B0A2 & $14.6 \pm 1.0 \mathrm{~b}$ & $73.3 \pm 1.6 \mathrm{a}$ & $36.8 \pm 1.3 \mathrm{de}$ \\
B1A2 & $12.9 \pm 1.1 \mathrm{~b}$ & $59.3 \pm 0.8 \mathrm{c}$ & $39.8 \pm 0.7 \mathrm{c}$ \\
B2A2 & $19.2 \pm 1.0 \mathrm{a}$ & $67.7 \pm 0.6 \mathrm{~b}$ & $49.5 \pm 2.1 \mathrm{a}$ \\
B3A2 & $14.6 \pm 1.1 \mathrm{~b}$ & $51.3 \pm 0.6 \mathrm{e}$ & $45.3 \pm 0.9 \mathrm{~b}$ \\
\hline
\end{tabular}

The treatments with single application of $A$. niger and coapplications of $B$. mucilaginosus and A. niger all showed a significant increase in the number of fungi, which reached a maximum of $73.3 \pm 1.6 \%\left(10^{2} \mathrm{CFU} / \mathrm{g}\right)$ for $\mathrm{B} 0 \mathrm{~A} 2$, followed by $67.7 \pm 0.6 \%\left(10^{2} \mathrm{CFU} / \mathrm{g}\right)$ for $\mathrm{B} 2 \mathrm{~A} 2$. In contrast, treatments with single applications of $B$. mucilaginosus were associated with a slight decrease in the number of fungi.

For actinomycetes, in general, there were no significant influences on their numbers by single applications of A. niger. Both coapplications of $B$. mucilaginosus and A. niger and single applications of $B$. mucilaginosus increased the number of actinomycetes, and the maximum appeared in B2A2 $(49.5 \pm 2.1 \%$ $10^{5} \mathrm{CFU} / \mathrm{g}$ ).

Our work also suggested the presence of a synergistic effect for the treatments with co-applications of $B$. mucilaginosus and $A$. niger ${ }^{[37]}$. This is reflected by an initial increase in the amount of soil microorganisms with increasing co-application concentrations and a decrease after the concentrations reached optimization.

\subsection{Effects of B. mucilaginosus and A. niger on soil microbial biomass}

The soil microbial biomass has extremely important functions in soil ecosystems, such as converting organic matter into nutrients that could be absorbed and utilized by plants, promoting organic carbon metabolism, and transferring nutrients in plants ${ }^{[38-40]}$. The soil microbial biomass carbon (MBC) and nitrogen (MBN) could be increased to various degrees by applications of $B$. mucilaginosus and A. niger, as shown in Table 4. High MBC and MBN were generally found in treatments with coapplications of $B$. mucilaginosus and $A$. niger, with maximum values of $(928.2 \pm 28.3 \%) \mathrm{mg} / \mathrm{kg}$ and $(105.2 \pm 2.4 \%) \mathrm{mg} / \mathrm{kg}$, respectively, for $\mathrm{B} 2 \mathrm{~A} 2$. Under single applications of $B$. mucilaginosus, the highest $\mathrm{MBC}$ and $\mathrm{MBN}$ were $(848.1 \pm 36.2 \%) \mathrm{mg} / \mathrm{kg}$ and $(78.0 \pm 0.4 \%)$ $\mathrm{mg} / \mathrm{kg}$, respectively, for B3A0. For single applications of A. niger, the highest $\mathrm{MBC}$ and $\mathrm{MBN}$ were $(529.5 \pm 8.4 \%) \mathrm{mg} / \mathrm{kg}$ and $(75.5 \pm 3.5 \%) \mathrm{mg} / \mathrm{kg}$, respectively, for $\mathrm{B} 0 \mathrm{~A} 2$. The results suggested that the high $\mathrm{MBC}$ and $\mathrm{MBN}$ obtained from the 
treatments with co-applications were likely attributed to interactions between B. mucilaginosus and A. niger ${ }^{[41]}$. However, an optimized amount existed for the co-applications, and when this value was surpassed, poisoning and inhibition of MBC and MBN occurred, e.g., the amounts of $\mathrm{MBC}$ and $\mathrm{MBN}$ were higher in $\mathrm{B} 2 \mathrm{~A} 2$ than in B3A2.

Table 4 Effect of $B$. mucilaginosus and A. niger on soil

\begin{tabular}{ccc}
\multicolumn{3}{c}{ microbial biomass } \\
\hline Treatment & $\begin{array}{c}\text { Microbial biomass carbon } \\
/ \mathrm{mg} \cdot \mathrm{kg}^{-1}\end{array}$ & $\begin{array}{c}\text { Microbial biomass nitrogen } \\
/ \mathrm{mg}^{-1} \mathrm{~kg}^{-1}\end{array}$ \\
\hline B0A0 & $433.5 \pm 25.9 \mathrm{e}$ & $54.1 \pm 1.5 \mathrm{e}$ \\
B1A0 & $556.5 \pm 35.4 \mathrm{~d}$ & $57.6 \pm 1.6 \mathrm{~d}$ \\
B2A0 & $776.0 \pm 38.9 \mathrm{bc}$ & $55.6 \pm 3.5 \mathrm{de}$ \\
B3A0 & $848.1 \pm 36.2 \mathrm{~b}$ & $58.7 \pm 2.0 \mathrm{~d}$ \\
B0A1 & $480.6 \pm 13.5 \mathrm{e}$ & $61.9 \pm 2.0 \mathrm{~d}$ \\
B1A1 & $618.6 \pm 34.6 \mathrm{~cd}$ & $71.1 \pm 0.9 \mathrm{c}$ \\
B2A1 & $848.8 \pm 35.5 \mathrm{~b}$ & $78.0 \pm 0.4 \mathrm{~b}$ \\
B3A1 & $919.2 \pm 21.1 \mathrm{a}$ & $79.3 \pm 0.2 \mathrm{~b}$ \\
B0A2 & $529.5 \pm 8.4 \mathrm{de}$ & $75.5 \pm 3.5 \mathrm{~b}$ \\
B1A2 & $691.0 \pm 19.4 \mathrm{c}$ & $83.8 \pm 4.1 \mathrm{~b}$ \\
B2A2 & $928.2 \pm 28.3 \mathrm{a}$ & $105.2 \pm 2.4 \mathrm{a}$ \\
B3A2 & $837.9 \pm 32.5 \mathrm{~b}$ & $101.4 \pm 2.9 \mathrm{a}$ \\
\hline
\end{tabular}

3.3 Effects of $B$. mucilaginosus and $A$. niger on soil enzyme activity

Soil enzyme (urease, acid phosphatase and invertase) activities reflect the direction and intensity of soil biochemical processes and are important biological indicators of soil fertility and the quality of the ecological environment ${ }^{[29]}$. Urease, acid phosphatase and invertase activities were all increased by the co-applications of $B$. mucilaginosus and A. niger, as shown in Table 5. The treatment B3A0 showed the highest urease, acid phosphatase and invertase activities under single application of $B$. mucilaginosus, whose trend is in agreement with previous work ${ }^{[37]}$. The treatment B0A2 exhibited the highest urease, acid phosphatase and invertase activities under the condition of a single application of A. niger. This may be due to the secretions of rice plant roots and microorganisms, which are correlated with the transformation of soil $\mathrm{P}$, since rice plants require large amounts of nutrients during maturity. When A. niger, a phosphate-solubilizing bacteria, was applied, a large amount of available $\mathrm{P}$ was transformed and could be absorbed and utilized by the rice plants. The soil enzyme activity was the strongest in the coapplications of B. mucilaginosus and a niger, which increased by $11.24 \%-15.49 \%$ and $14.90 \%$ $26.52 \%$, respectively, compared with that of single applications of B. mucilaginosus and A. niger, respectively. Note that the treatments with coapplications of B. mucilaginosus and A. niger were also $39.87 \%$ higher than the control-blank treatment (B0A0). In addition, the activity of the soil enzymes began to decrease slightly with an excessive amount of the co-applications, i.e., higher activity for $\mathrm{B} 2 \mathrm{~A} 2$ than $\mathrm{B} 3 \mathrm{~A} 2$, also indicating that a poisoning effect occurred ${ }^{[42]}$.

\subsection{Effects of $B$. mucilaginosus and $A$. niger on soil} biochemical activity

Soil biochemical activity refers to the ability of soil microbes and enzymes to decompose substrates or form products at a certain temperature per unit time. Therefore, the application of an appropriate number of microorganisms will have an impact on the life activities and strength of microorganisms in the soil and will also indirectly affect the intensity of various biochemical activities in soil ${ }^{[43]}$.
Table 5 Effects of $B$. mucilaginosus and A. niger on soil enzyme activities

\begin{tabular}{cccc}
\hline Treatments & $\begin{array}{c}\text { Urease } \\
/ \mathrm{mg} \cdot \mathrm{L}^{-1}\end{array}$ & $\begin{array}{c}\text { Acid phosphatase } \\
/ \mathrm{mg} \cdot \mathrm{L}^{-1}\end{array}$ & $\begin{array}{c}\text { Invertase } \\
/ \mathrm{mg} \cdot \mathrm{L}^{-1}\end{array}$ \\
\hline B0A0 & $4.74 \pm 0.14 \mathrm{e}$ & $25.70 \pm 1.02 \mathrm{~d}$ & $7.1 \pm 0.99 \mathrm{~d}$ \\
B1A0 & $7.81 \pm 0.3 \mathrm{a}$ & $31.31 \pm 1.49 \mathrm{c}$ & $10.57 \pm 0.78 \mathrm{c}$ \\
B2A0 & $7.21 \pm 0.22 \mathrm{ab}$ & $32.66 \pm 1.93 \mathrm{bc}$ & $11.28 \pm 1.27 \mathrm{c}$ \\
B3A0 & $7.47 \pm 0.3 \mathrm{a}$ & $39.72 \pm 0.73 \mathrm{a}$ & $11.57 \pm 1.15 \mathrm{c}$ \\
B0A1 & $5.24 \pm 0.35 \mathrm{de}$ & $34.77 \pm 0.73 \mathrm{bc}$ & $12.21 \pm 0.57 \mathrm{bc}$ \\
B1A1 & $4.81 \pm 0.53 \mathrm{e}$ & $32.57 \pm 0.51 \mathrm{bc}$ & $12.46 \pm 0.12 \mathrm{bc}$ \\
B2A1 & $5.25 \pm 0.58 \mathrm{cde}$ & $33.25 \pm 2.04 \mathrm{bc}$ & $12.16 \pm 0.45 \mathrm{bc}$ \\
B3A1 & $6.24 \pm 0.38 \mathrm{a}$ & $34.36 \pm 0.80 \mathrm{bc}$ & $11.83 \pm 1.29 \mathrm{bc}$ \\
B0A2 & $5.77 \pm 0.14 \mathrm{~cd}$ & $42.83 \pm 4.44 \mathrm{a}$ & $13.65 \pm 0.37 \mathrm{~b}$ \\
B1A2 & $4.88 \pm 0.22 \mathrm{e}$ & $31.60 \pm 2.09 \mathrm{c}$ & $12.29 \pm 1.34 \mathrm{bc}$ \\
B2A2 & $6.63 \pm 0.75 \mathrm{~b}$ & $36.09 \pm 3.58 \mathrm{~b}$ & $15.58 \pm 1.07 \mathrm{a}$ \\
B3A2 & $5.85 \pm 0.26 \mathrm{c}$ & $34.11 \pm 1.97 \mathrm{bc}$ & $11.21 \pm 1.02 \mathrm{c}$ \\
\hline
\end{tabular}

Applications of B. mucilaginosus and A. niger could affect the soil biochemical activity (organic $\mathrm{P}$ and inorganic $\mathrm{P}, \mathrm{K}$-releasing ability), as shown in Table 6. For single applications of $B$. mucilaginosus, the highest intensity of organic $\mathrm{P}$ appeared in $\mathrm{B} 3 \mathrm{~A} 0$ $(17.53 \pm 0.91) \mathrm{mg} / \mathrm{L}$. The increase is due to the P-releasing and $\mathrm{K}$-releasing abilities of $B$. mucilaginosus, consistent with previous works $^{[44,45]}$. For single applications of $A$. niger, the highest intensity of conversion of organic P appeared in B0A2 (19.11 \pm 1.01$)$ $\mathrm{mg} / \mathrm{L}$, which is due to the organic and inorganic $\mathrm{P}$ in the soil being dissolved by A. niger and then absorbed by the rice plants. For coapplications of $B$. mucilaginosus and A. niger, the intensity of conversion of organic $\mathrm{P}$ increased by $24.30 \%-39.2 .3 \%$ and $14.02 \%-26.46 \%$, respectively, compared with that with single applications of B. mucilaginosus and A. niger. This figure was also increased by $37.04 \%$ compared with that of the control-blank treatment (B0A0). The results indicated a synergistic effect between $B$. mucilaginosus and A. niger, leading to increased soil organic $\mathrm{P}$ conversion intensities.

Table 6 Effects of $B$. mucilaginosus and A. niger on soil biochemical activity intensity

\begin{tabular}{cccc}
\hline Treatment & $\begin{array}{c}\text { Conversion of } \\
\text { Organic P/mg } \cdot \mathrm{L}^{-1}\end{array}$ & $\begin{array}{c}\text { Conversion of } \\
\text { Inorganic P/mg } \cdot \mathrm{L}^{-1}\end{array}$ & $\begin{array}{c}\text { K-releasing ability } \\
/ \mathrm{mg} \cdot \mathrm{L}^{-1}\end{array}$ \\
\hline B0A0 & $15.9 \pm 0.99 \mathrm{~d}$ & $99.5 \pm 6.89 \mathrm{a}$ & $11.83 \pm 0.91 \mathrm{e}$ \\
B1A0 & $15.65 \pm 1.05 \mathrm{~d}$ & $100.5 \pm 4.8 \mathrm{a}$ & $13.21 \pm 0.34 \mathrm{~d}$ \\
B2A0 & $16.75 \pm 1.12 \mathrm{~cd}$ & $101.5 \pm 6.6 \mathrm{a}$ & $15.01 \pm 0.9 \mathrm{bc}$ \\
B3A0 & $17.53 \pm 0.91 \mathrm{~cd}$ & $106.3 \pm 4.5 \mathrm{a}$ & $17.00 \pm 1.5 \mathrm{a}$ \\
B0A1 & $17.23 \pm 1.09 \mathrm{~cd}$ & $100.9 \pm 3.8 \mathrm{a}$ & $11.62 \pm 1.23 \mathrm{e}$ \\
B1A1 & $18.06 \pm 0.89 \mathrm{c}$ & $99.9 \pm 7.6 \mathrm{a}$ & $14.8 \pm 1.23 \mathrm{bc}$ \\
B2A1 & $19.13 \pm 1.06 \mathrm{~b}$ & $104.8 \pm 6.5 \mathrm{a}$ & $15.81 \pm 0.91 \mathrm{ab}$ \\
B3A1 & $19.84 \pm 0.88 \mathrm{ab}$ & $102.4 \pm 2.9 \mathrm{a}$ & $16.581 .24 \mathrm{ab}$ \\
B0A2 & $19.11 \pm 1.01 \mathrm{~b}$ & $103.0 \pm 4.6 \mathrm{a}$ & $12.51 \pm 0.90 \mathrm{de}$ \\
B1A2 & $19.73 \pm 1.13 \mathrm{ab}$ & $104.3 \pm 5.1 \mathrm{a}$ & $13.79 \pm 1.19 \mathrm{~cd}$ \\
B2A2 & $21.79 \pm 1.17 \mathrm{a}$ & $104.5 \pm 6.9 \mathrm{a}$ & $16.98 \pm 0.59 \mathrm{a}$ \\
B3A2 & $20.41 \pm 0.93 \mathrm{a}$ & $101.9 \pm 3.8 \mathrm{a}$ & $16.53 \pm 1.19 \mathrm{ab}$ \\
\hline
\end{tabular}

There were no significant effects on the intensity of conversion of soil inorganic $\mathrm{P}$ by applications of B. mucilaginosus and A. niger, indicating that they did not have the ability to convert or dissolve inorganic $\mathrm{P}$.

Both B. mucilaginosus and A. niger showed some effects on the soil K-releasing ability to varying degrees. The highest K-releasing ability occurred in B3A0 (17.00 \pm 1.5$)$, followed by B2A2 (16.98 \pm 0.59$)$. This is because B. mucilaginosus, a 
K-soluble functional bacterium, had the ability to decompose potassium aluminum silicate minerals in the soil ${ }^{[46,47]}$.

\subsection{Effects of $B$. mucilaginosus and $A$. niger on soil nutrient contents}

The soil nutrient contents (available $\mathrm{Si}$, alkali-hydrolyzable N, available $\mathrm{P}$ and available $\mathrm{K}$ ) could be affected by the applications of $B$. mucilaginosus and $A$. niger to various extents. As shown in Table 7, the contents of soil available Si were the highest for the treatments with coapplications of B. mucilaginosus and A. niger, followed by the treatments with single application of $B$. mucilaginosus. The highest content of soil available $\mathrm{Si}$ appeared in treatment B2A2 $(344.6 \pm 2.5 \mathrm{mg} / \mathrm{kg})$, which was mainly attributed to the effect of B. mucilaginosus, similar to the trend reported previously ${ }^{[48]}$. Many previous reports suggested that $B$. mucilaginosus can dissolve minerals and release $\mathrm{Si}$ from the crystal lattice of minerals in soil ${ }^{[49,50]}$. For the treatments with single application of A. niger, the soil available $\mathrm{Si}$ was relatively low. This is because the available $\mathrm{Si}$ content in the soil is dependent on $\mathrm{pH}$. However, the $\mathrm{pH}$ range of A. niger, being a phosphate-solubilizing bacterium, is between 2 and 3. When $A$. niger is applied, the $\mathrm{pH}$ is reduced, resulting in the inhibition of the dissolution of available $\mathrm{Si}$ in the soil ${ }^{[51]}$. For coapplications of $B$. mucilaginosus and A. niger, the available Si content in the soil still increased, suggesting that the negative effects of the application of A. niger were relieved by coapplications. Note that the trend of soil available $\mathrm{Si}$ first increased and then decreased with the concentration of the coapplications, which is also due to the antagonistic effect induced when excessive amounts of $A$. niger were applied.

Table 7 Effects of $B$. mucilaginosus and A. niger on soil nutrient contents

\begin{tabular}{ccccc}
\hline Treatments & $\begin{array}{c}\text { Available Si } \\
/ \mathrm{mg} \cdot \mathrm{kg}^{-1}\end{array}$ & $\begin{array}{c}\text { Alkali-hydrolyzable N } \\
/ \mathrm{mg} \cdot \mathrm{kg}^{-1}\end{array}$ & $\begin{array}{c}\text { Available P } \\
/ \mathrm{mg}^{-1} \mathrm{~kg}^{-1}\end{array}$ & $\begin{array}{c}\text { Available K } \\
/ \mathrm{mg} \cdot \mathrm{kg}^{-1}\end{array}$ \\
\hline B0A0 & $308.7 \pm 6.9 \mathrm{~cd}$ & $90.2 \pm 4.1 \mathrm{~d}$ & $6.8 \pm 1.2 \mathrm{~d}$ & $166.6 \pm 1.8 \mathrm{bc}$ \\
B1A0 & $312.4 \pm 8.3 \mathrm{c}$ & $103.4 \pm 3.5 \mathrm{~cd}$ & $10.5 \pm 1.3 \mathrm{~cd}$ & $188.4 \pm 6.3 \mathrm{~b}$ \\
B2A0 & $336.2 \pm 10.9 \mathrm{a}$ & $107.3 \pm 6.2 \mathrm{c}$ & $11.5 \pm 1.0 \mathrm{c}$ & $217.6 \pm 11.8 \mathrm{a}$ \\
B3A0 & $315.9 \pm 11.0 \mathrm{~cd}$ & $100.6 \pm 6.1 \mathrm{~cd}$ & $9.0 \pm 0.6 \mathrm{~cd}$ & $216.6 \pm 13.7 \mathrm{a}$ \\
B0A1 & $301.0 \pm 7.8 \mathrm{de}$ & $100.9 \pm 4.1 \mathrm{~cd}$ & $12.6 \pm 1.0 \mathrm{bc}$ & $157.0 \pm 3.6 \mathrm{c}$ \\
B1A1 & $306.2 \pm 7.5 \mathrm{de}$ & $111.3 \pm 6.0 \mathrm{bc}$ & $11.9 \pm 1.3 \mathrm{c}$ & $159.1 \pm 11.0 \mathrm{c}$ \\
B2A1 & $320.3 \pm 7.5 \mathrm{bc}$ & $120.1 \pm 2.6 \mathrm{~b}$ & $12.8 \pm 1.0 \mathrm{bc}$ & $179.0 \pm 1.8 \mathrm{~b}$ \\
B3A1 & $340.2 \pm 8.4 \mathrm{a}$ & $131.3 \pm 7.7 \mathrm{ab}$ & $14.5 \pm 1.4 \mathrm{ab}$ & $208.7 \pm 0.9 \mathrm{a}$ \\
B0A2 & $297.0 \pm 11.4 \mathrm{de}$ & $107.6 \pm 4.0 \mathrm{c}$ & $10.9 \pm 1.6 \mathrm{c}$ & $143.9 \pm 2.5 \mathrm{~d}$ \\
B1A2 & $335.1 \pm 4.7 \mathrm{ab}$ & $113.2 \pm 0.5 \mathrm{bc}$ & $14.6 \pm 0.8 \mathrm{ab}$ & $169.5 \pm 7.9 \mathrm{bc}$ \\
B2A2 & $344.6 \pm 2.5 \mathrm{a}$ & $133.8 \pm 5.8 \mathrm{ab}$ & $15.9 \pm 1.3 \mathrm{a}$ & $180.1 \pm 16.2 \mathrm{~b}$ \\
B3A2 & $337.1 \pm 12.6 \mathrm{a}$ & $145.0 \pm 14.5 \mathrm{a}$ & $14.9 \pm 1.6 \mathrm{ab}$ & $184.6 \pm 9.3 \mathrm{~b}$ \\
\hline
\end{tabular}

The content of alkali-hydrolyzable $\mathrm{N}$ was increased significantly by applications of $B$. mucilaginosus and A. niger. In general, the contents for the treatments with coapplications of $B$. mucilaginosus and $A$. niger were higher than those for treatments with the single applications of B. mucilaginosus and Aspergillus niger.

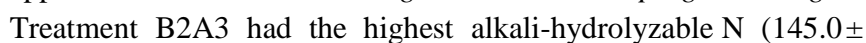
$14.5 \mathrm{mg} / \mathrm{kg})$, followed by treatment B2A2 $(133.8 \pm 5.8 \mathrm{mg} / \mathrm{kg})$.

The content of soil available $\mathrm{P}$ was improved to various degrees by the applications of B. mucilaginosus and A. niger. The effect is expressed as coapplications of $B$. mucilaginosus and $A$. niger $>$ single applications of $A$. niger $>$ single applications of B. mucilaginosus. The soil available $\mathrm{P}$ content was the highest for the B2A2 treatment $(133.8 \pm 5.8 \mathrm{mg} / \mathrm{kg})$.

The content of the soil available $\mathrm{K}$ was significantly increased by single applications of $B$. mucilaginosus and coapplications of $B$. mucilaginosus and A. niger. For the treatments with single applications of $B$. mucilaginosus, the content of soil available $\mathrm{K}$ increased steadily with increasing amounts of the bacteria, which is consistent with the positive correlation between soil K-releasing strength and the amount of B. mucilaginosus applied. In contrast, a single application of $A$. niger resulted in a decreased content of available $\mathrm{K}$ in the soil, suggesting that it had an antagonistic effect. However, for coapplications of B. mucilaginosus and Aspergillus niger, improvement of the available $\mathrm{K}$ content suggested that this antagonistic effect could be mitigated.

Many previous studies showed that in applying microbial inoculants, the contents of alkali hydrolyzable $\mathrm{N}$, available $\mathrm{P}$ and available $\mathrm{K}$ in the soil could be increased ${ }^{[52,53]}$. This is because the microbial inoculants applied can increase the $\mathrm{N}$ in soil by $\mathrm{N}$-fixation and the conversion rate and utilization rate of poorly soluble $\mathrm{P}, \mathrm{K}$ and other nutrients in the soil through microbial activities $^{[52,53]}$. Our results also showed that the applications of $B$. mucilaginosus and $A$. niger resulted in similar trends. Furthermore, among the three types of treatments, the content of soil alkali-hydrolysable $\mathrm{N}$ and available $\mathrm{P}$ in the treatments with co-applications of B. mucilaginosus and A. niger showed the highest increase, indicating that co-applications played a mutually reinforcing role, consistent with a trend reported in previous work $^{[54]}$.

3.6 Effects of $B$. mucilaginosus and $A$. niger on the nutrient content in the above-ground parts of the rice plant

The nutrient contents ( $\mathrm{Si}, \mathrm{N}, \mathrm{P}$ and $\mathrm{K}$ ) in the above-ground parts of the rice plant (stem, leaf and spike) could be affected by the application of B. mucilaginosus and A. niger to various extents, as shown in Figure 1. The highest nutrient contents generally appeared in the treatments with coapplications of $B$. mucilaginosus and A. niger.

Our study showed that applications of both B. mucilaginosus and A. niger could affect the content of available $\mathrm{Si}$ in various organs of the above-ground part of the rice plant (Figure 1). The absorption and accumulation of $\mathrm{Si}$ could be promoted, and the distribution of $\mathrm{Si}$ in the stems, leaves and spikes could be affected $^{[55]}$. The content of available $\mathrm{Si}$ from high to low is ranked as: leaves, stems, spikes. This is because the deposition of $\mathrm{Si}$ in rice plants is a passive physical process that is affected by transpiration. When water is evaporated from the epidermis of the leaves, stems and other organs, the silicic acid reaches super saturation and spontaneously polymerizes into insoluble silica gel, resulting in immobilization and inability of redistribution ${ }^{[56]}$. Since the main organs for plant transpiration are the leaves, the $\mathrm{Si}$ content of the leaves is significantly higher than in other organs ${ }^{[57,58]}$. The content of available $\mathrm{Si}$ in the stems of rice plants was the highest for the $\mathrm{B} 2 \mathrm{~A} 2$ treatment $(53.1 \pm 2.1 \mathrm{~g} / \mathrm{kg})$, followed by the B2A0 treatment $(53.0 \pm 1.3 \mathrm{~g} / \mathrm{kg})$. The content of available $\mathrm{Si}$ in the leaves was the highest for the B2A2 treatment, followed by the B2A3 treatment. The content of the available $\mathrm{Si}$ in the spike of the rice plant was lower than that of the conventional fertilization (B0A0) treatment.

$\mathrm{N}, \mathrm{P}$ and $\mathrm{K}$ are the three major nutrients of rice plants, which closely interact with each other. The application of one of the nutrients can promote the absorption and utilization of the other two nutrients by the soil. Applications of both $B$. mucilaginosus and $A$. niger resulted in an increase in the $\mathrm{N}$ content in the above-ground tissues of the rice plants by various degrees (Figure 2). The absorbed and accumulated $\mathrm{N}$ in rice plants further affected the distribution of $\mathrm{N}$ in the stems, leaves and spikes. In 
general, the distribution of $\mathrm{N}$ was spikes > leaves> stems. This is because $\mathrm{N}$ content and nutrients in rice plants gradually transfer to the spikes as the growth period progresses, promoting grain formation $^{[13,59,60]}$. For the stems of the rice plants, the highest content of $\mathrm{N}$ appeared in B2A2 $(6.95 \pm 0.26 \mathrm{~g} / \mathrm{kg})$, followed by B1A2 $(6.72 \pm 0.15 \mathrm{~g} / \mathrm{kg})$. For the leaves of the rice plants, the highest content of $\mathrm{N}$ appeared in B2A2 $(13.80 \pm 0.62 \mathrm{~g} / \mathrm{kg})$, followed by B3A2 $(13.85 \pm 0.28 \mathrm{~g} / \mathrm{kg})$. For the spikes of the rice plants, the highest content of $\mathrm{N}$ appeared in B2A0 (23.67 \pm 1.03$)$, followed by B2A2 $(23.42 \pm 0.32 \mathrm{~g} / \mathrm{kg})$.

The $\mathrm{P}$ content of the above-ground parts of the rice plants could also be improved by applications of both B. mucilaginosus and $A$. niger (Figure 3). In the stems of the rice plants, the content of P was the highest for B2A2 $(2.23 \pm 0.13 \mathrm{~g} / \mathrm{kg})$, which was $12.62 \%$ higher than that of the conventional treatment (B0A0). In the leaves of the rice plants, the content of $\mathrm{P}$ was the highest for $\mathrm{B} 2 \mathrm{~A} 3$ $(1.56 \pm 0.09)$, followed by B2A2 $(1.54 \pm 0.08 \mathrm{~g} / \mathrm{kg})$. In the spikes of the rice plants, the content of $\mathrm{P}$ was the highest for $\mathrm{B} 2 \mathrm{~A} 2$ $(2.30 \pm 0.16 \mathrm{~g} / \mathrm{kg})$, followed by B3A1 $(2.24 \pm 0.11 \mathrm{~g} / \mathrm{kg})$. The applications of $B$. mucilaginosus significantly increased the $\mathrm{P}$ content in the stems, leaves and spikes of rice plants observed here, similar to that reported previously ${ }^{[53,60,61]}$.

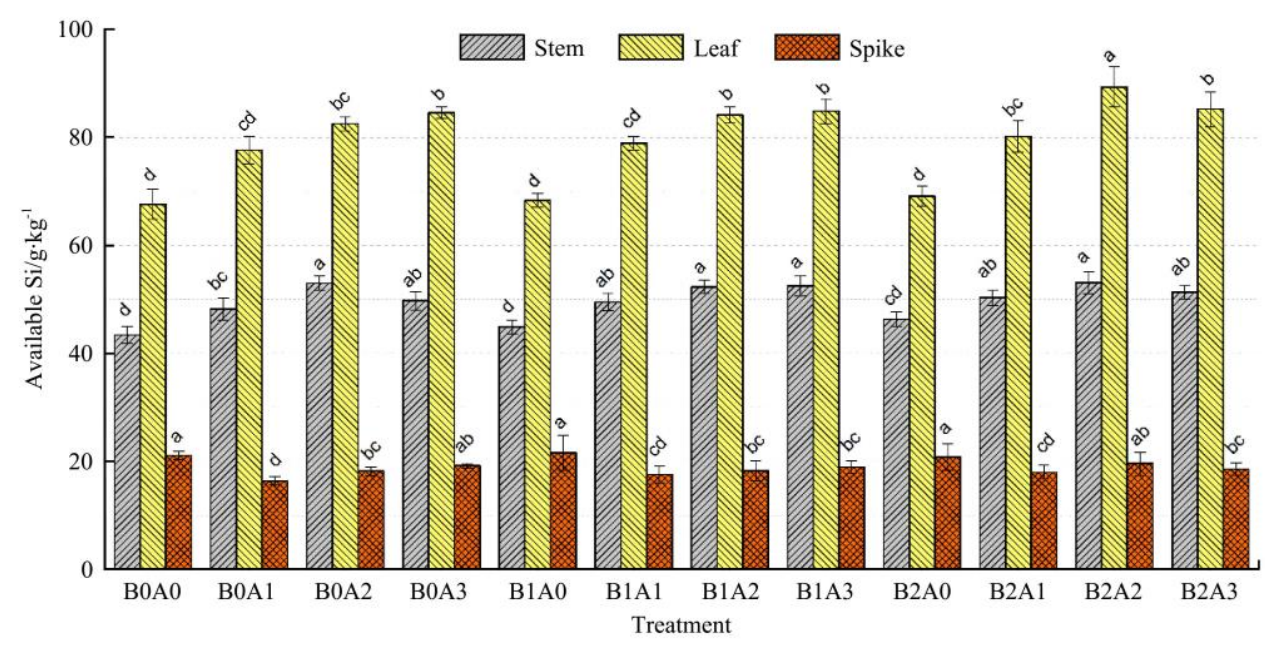

Figure 1 Effects of B. mucilaginous and A. niger on the available Si of the above-ground (stems, leaves and spikes) parts of the rice plant

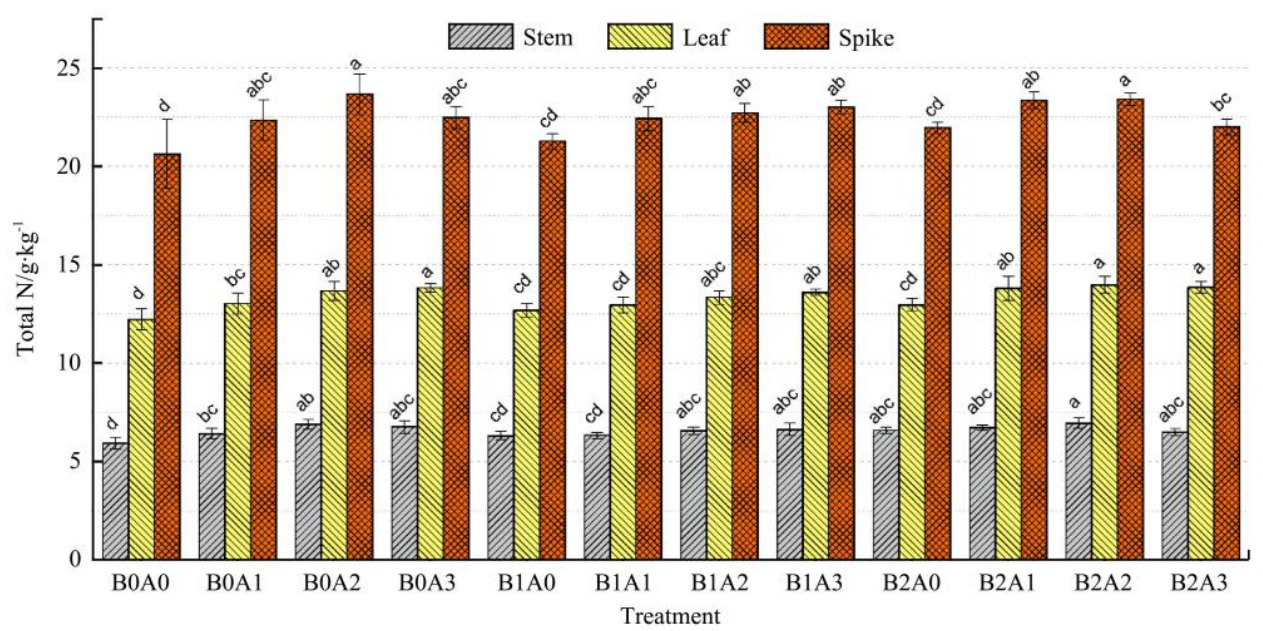

Figure 2 Effects of B. mucilaginous and A. niger on the total $\mathrm{N}$ of the above-ground (stems, leaves and spikes) parts of the rice plant

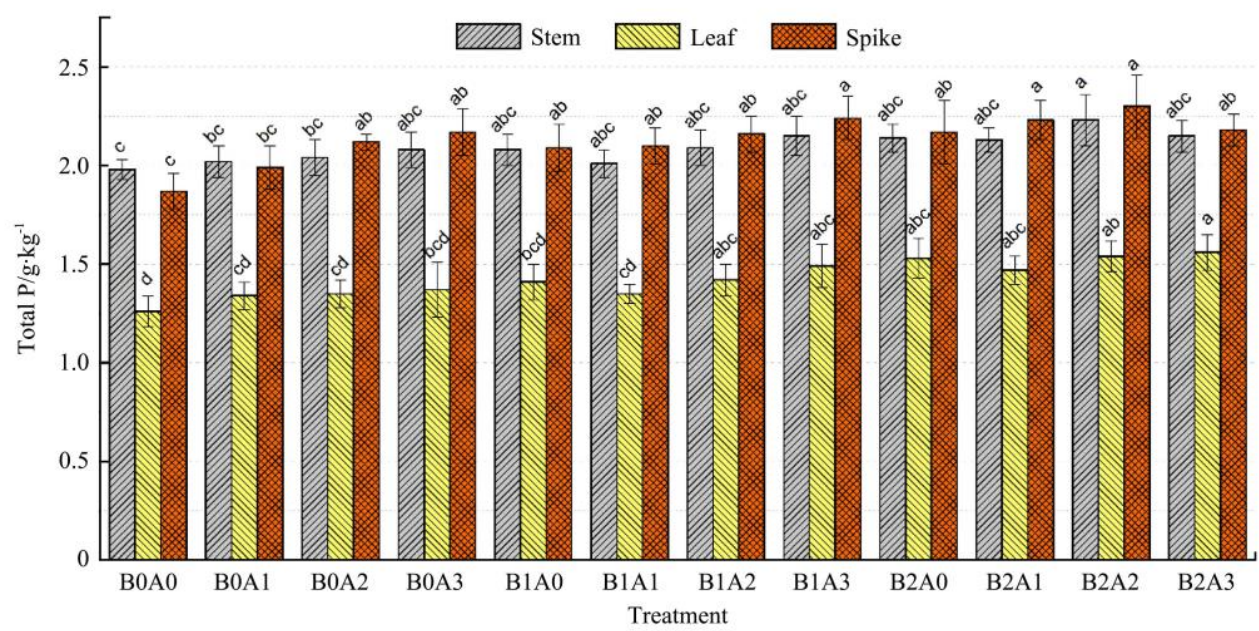

Figure 3 Effects of B. mucilaginous and A. niger on the total $\mathrm{P}$ of the above-ground (stems, leaves and spikes) parts of the rice plant 
The application of B. mucilaginosus significantly increased the $\mathrm{K}$ content in the stems, leaves and spikes of the rice plants (Figure 4). The application amount was positively correlated with the K content of various organs. The single applications (B1A0 and $\mathrm{B} 2 \mathrm{~A} 0$ ) of A. niger had no effect on the aboveground $\mathrm{K}$ content of rice plants compared with that of the control-blank treatment (B0A0). For the treatments with co-applications of $B$. mucilaginosus and $A$. niger, the $\mathrm{K}$ content in the above-ground parts of the rice plants was increased, but the extent was slightly lower than that of the single applications of B. mucilaginosus.

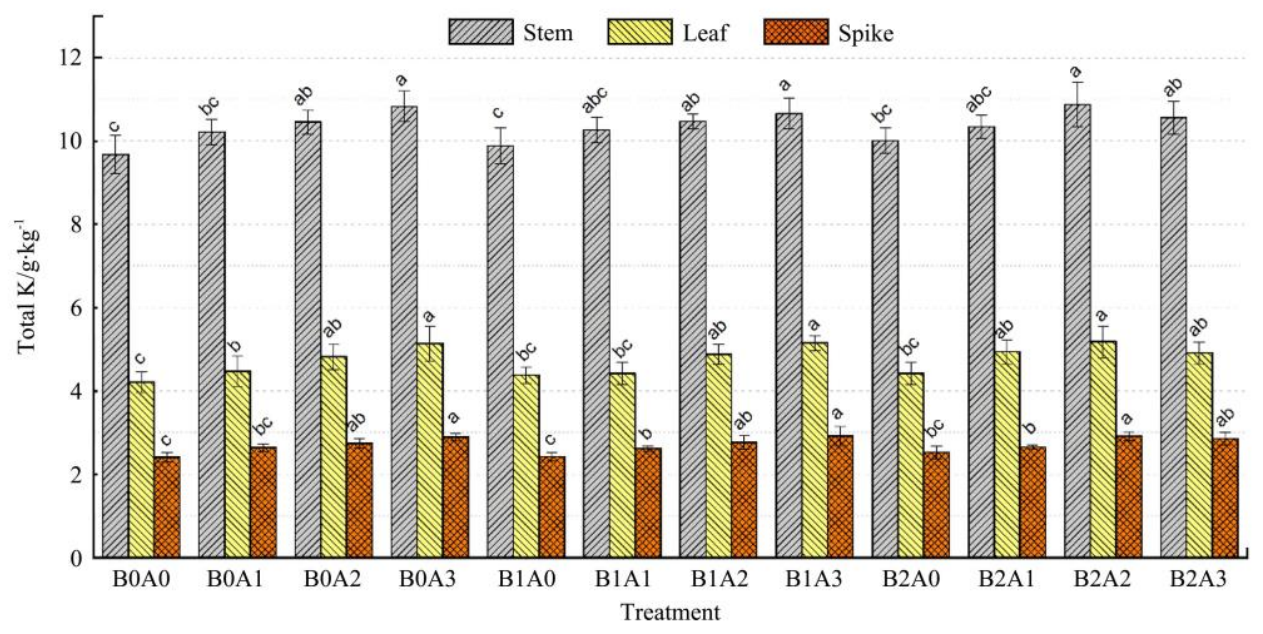

Figure 4 Effects of B. mucilaginous and A. niger on the total K of the above-ground (stems, leaves and spikes) parts of the rice plant

\subsection{Effects of B. mucilaginosus and A. niger on the yield of rice}

Our results showed that applications of B. mucilaginosus and $A$. niger resulted in increased yields of the rice plants to various degrees (2.62\%-21.20\%) compared with that of the control-blank treatment (B0C0) (Figure 5). The highest increase was observed in the treatments with co-applications of $B$. mucilaginosus and $A$.

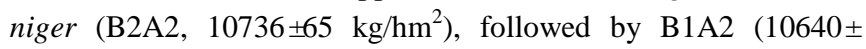
$105 \mathrm{~kg} / \mathrm{hm}^{2}$ ). In contrast, single applications of A. niger had almost no effect on the rice yield, indicating that the application of B. mucilaginosus was the main cause of the rice yield increases.

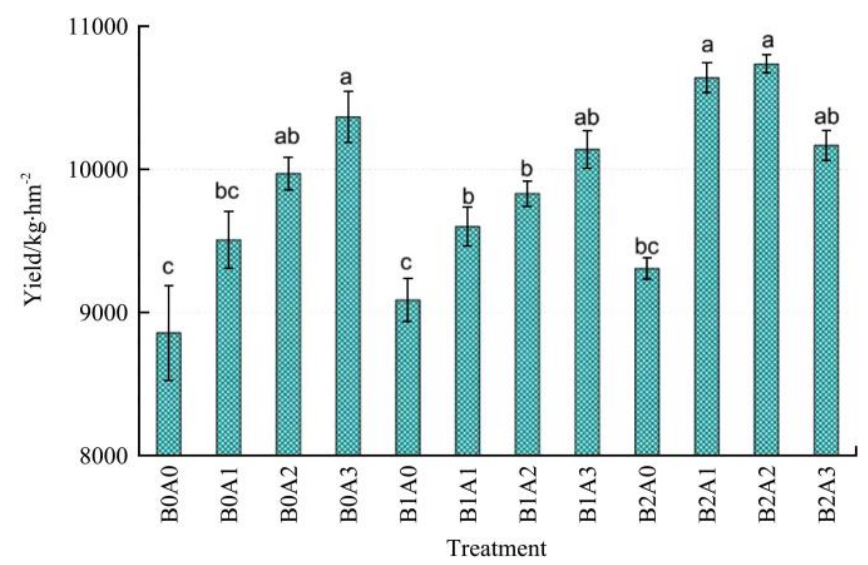

Figure 5 Effects of B. mucilaginous and A. niger on the yield of rice

It has been suggested that applications of Si fertilizer on rice plants can significantly promote the development of rice roots, resulting in larger stems, improved disease resistance, enhanced lodging resistance, increased grain numbers per spike, increased 1000 -grain weight and significantly increased yield ${ }^{[62-64]}$. Our work showed that applications of B. mucilaginosus could increase the Si content in rice plants, resulting in an effect similar to that of $\mathrm{Si}$ fertilizer. This is attributed to the fact that B. mucilaginosus can decompose $\mathrm{K}$ and $\mathrm{P}$ minerals such as phosphorus lime and feldspar in the soil into available $\mathrm{K}$ and $\mathrm{P}$ that can be absorbed and utilized by the rice plants, resulting in improved nutritional conditions. Meanwhile, the phytohormone produced by the metabolic activities of $B$. mucilaginosus promotes the growth of the roots of the rice plant, thereby increasing the absorption of soil elements and consequently increasing the yield.

For the treatments with co-applications of B. mucilaginosus and $A$. niger, the yield of rice increased significantly, which was higher than in the treatments with single applications, indicating strong interactions between B. mucilaginosus and A. niger. However, when the amount of $B$. mucilaginosus was low in the coapplications (e.g., B1A1, B1A2), the yield only increased slightly. This is because rice plants have a certain competitive effect on the absorption of $\mathrm{Si}$ and $\mathrm{P}$, i.e., excessive $\mathrm{Si}$ in the soil can inhibit the excessive absorption of $\mathrm{P}$ by rice plants, and deficient $\mathrm{Si}$ in soil can promote the absorption of $\mathrm{P}$ by rice plants ${ }^{[65,66]}$. When $\mathrm{P}$ is present in excessive concentrations in the soil, increasing $\mathrm{Si}$ can reduce the absorption of $\mathrm{P}$ by rice plants to avoid the excessive $\mathrm{P}$ affecting the normal maturity of the rice plants. Another factor contributing to the increase in crop yield is that by improving the nutrient environment of the crop, releasing hormones and plant stress resistance being enhanced, then plant diseases and pests can be inhibited to some extent, thereby reducing yield loss.

To ensure the realization of the goal of "One Regulatory, Two Reduction and Three Basic" by 2020, effectively guarantee the food supply security in China, agricultural product quality and agricultural environment, especially the production environment, and achieve the goal of reducing weight and increasing efficiency, we have promoted our research results into parts of northeast China, currently, farmers have achieved good economic benefits. In 2017, Shangzhi city rice cooperative have applied the bacterial agent on $10 \mathrm{hm}^{2}$ of land, based on microbial agents for $6 \mathrm{Yuan} / \mathrm{kg}$, when rice is 4 Yuan $/ \mathrm{kg}$. After testing, the yield of conventional fertilization was $8625 \mathrm{~kg} / \mathrm{hm}^{2}$, and the yield of the plots with microbial inoculum was $9574 \mathrm{~kg} / \mathrm{hm}^{2}$, the application of microbial agents increased yield by $11 \%$, economic benefit increased by 3378 Yuan $/ \mathrm{hm}^{2}$. In 2016, Qianpaoshou village of Shuangcheng city applied the bacterial agent on $3.3 \mathrm{hm}^{2}$ of land, the application of microbial agents increased yield by $12.5 \%$, economic benefit increased by 5558 Yuan/ $/ \mathrm{hm}^{2}$. 


\section{Conclusions}

In this work, the results showed that co-applications of $B$. mucilaginosus and $A$. niger had significant effects on the improvement of soil microorganisms, microbial biomass, enzyme and biochemical activities and plant nutrient contents. Furthermore, the combination of B. mucilaginosus and A. niger had a synergistic effect, which resulted in better effect than single applications of $B$. mucilaginosus or single applications of A. niger. Considering the yields, plant nutrient contents, availability of $\mathrm{Si}$ in paddy fields and soil ecological effects, the optimized combination was $120 \times 10^{11} \mathrm{CFU} / \mathrm{hm}^{2}$ for B. mucilaginosus and $15 \times 10^{11} \mathrm{CFU} / \mathrm{hm}^{2}$ for A. niger.

The development of microbial fertilizers should focus on the following aspects: research on the molecular basis of microbial inoculants, screening and mutagenesis of excellent strains, improving the stability and competitiveness of bacterial species; clarifying the mechanism and ecological role of microbial inoculants; improving the product standard of microbial fertilizer, strengthen the quality supervision and management of microbial fertilizer; standardize the detection methods of microbial fertilizers and develop rapid detection techniques.

Through this study, it can be found that fertilizer and microbial agents can improve the utilization rate of nutrients in food production. In the future, the research will be focused on developing a one-off organic or inorganic compound fertilizer and bio-fertilizer, in order to provide a theoretical basis for the protection and utilization of soil in northeast China and developing more environmental efficient green bio-bacterial manure.

\section{Acknowledgement}

This work was supported by Research Science Foundation in Technology Innovation of Harbin (Grant No. RC2013XK002015).

\section{[References]}

[1] Zhu H J, Sun L F, Zhang Y F, Zhang X L, Qiao J J. Conversion of spent mushroom substrate to biofertilizer using a stress-tolerant phosphate-solubilizing Pichia farinose FL7. Bioresource Technology, 2012; 111: 410-416.

[2] Zhao Z P, Yan S, Liu F, Ji P H, Wang X Y, Tong Y A. Effects of chemical fertilizer combined with organic manure on Fuji apple quality, yield and soil fertility in apple orchard on the Loess Plateau of China. Int J Agric \& Biol Eng, 2014; 7(2): 45-55.

[3] Zhao Z P, Duan M, Yan S, Liu Z F, Wang Q, Fu J, et al. Effects of different fertilizations on fruit quality, yield and soil fertility in field-grown kiwifruit orchard. Int J Agric \& Biol Eng, 2017; 10(2): 162-171.

[4] Ahmed F, Sultana R, Ahmed O, Akhtaruzzaman M, Iqbal M T. Roles of different fertilizer management practices on mulberry leaf yield and quality. Int J Agric \& Biol Eng, 2017; 10(5): 104-114.

[5] Khush G S. What it will take to feed 5.0 billion rice consumers in 2030. Plant Molecular Biology, 2005; 59(1): 1-6.

[6] IRRI (International Rice Research Institute) (2003) World rice statistics. http://www.irri.org/science/ricestat/index.asp.

[7] Yang Z, Chen F S, Wu X Q, Luan F G, Zhang L P, Fang X M, et al. Isolation and characterization of two phosphate-solubilizing fungi from rhizosphere soil of moso bamboo and their functional capacities when exposed to different phosphorus sources and $\mathrm{pH}$ environments. Plos One, 2018; 13(7): e0199625.

[8] Kumar S, Gaind S. Fermentative production of soluble phosphorus fertilizer using paddy straw: an alternate to biomass burning. International Journal of Environmental Science and Technology, 2019; 16(10): 6077-6088.

[9] Khan K S, Joergensen RG. Changes in microbial biomass and P fractions in biogenic household waste compost amended with inorganic $\mathrm{P}$ fertilizers. Bioresource Technology, 2009; 100(1): 303-309.

[10] Hinsinger P. Bioavailability of soil inorganic P in the rhizosphere as affected by root-induced chemical changes: A review. Plant and Soil, 2001; 237(2): 173-195.

[11] Gichangi E M, Mnkeni P N S, Brookes P C. Effects of goat manure and inorganic phosphate addition on soil inorganic and microbial biomass phosphorus fractions under laboratory incubation conditions. Soil Science and Plant Nutrition, 2009; 55(6): 764-771.

[12] Savci S. Investigation of effect of chemical fertilizers on environment In: Dan Y, editor. International Conference on Environmental Science and Development. APCBEE Procedia, 2012; pp.287-292.

[13] Mercl F, Tejnecký V, Ságová-Marečková M, Dietel K, Kopecký J, Břendová $\mathrm{K}$, et al. Co-application of wood ash and Paenibacillus mucilaginosus to soil: the effect on maize nutritional status, root exudation and composition of soil solution. Plant and Soil, 2018; 428(1): 105-122.

[14] Zheng G X, Zhou C Y, Yin T, Lu Z X, Ai S. Optimization of fermentation factors to enhance rice straw degradation ability using a microbial consortium LZF-12. Int J Agric \& Biol Eng, 2019; 12(3): 168-173.

[15] Gou X M, Zhang R P, Zhang Y Y, Yu W, Cai Y, Yang J W, et al. Effect of microbial fertilizers added into seedbed on microbial biomass carbon and nitrogen in rhizosphere of tobacco soil. Journal of Sichuan Agricultural University, 2019: 37(3): 338-342,351. (in Chinese)

[16] Gamal-Eldin H, Elbanna K. Field evidence for the potential of rhodobacter capsulatus as biofertilizer for flooded rice. Current Microbiology, 2011; 62(2): 391-395.

[17] Zhang X W. Advances in biological nitrogen fixation mechanisms. Chinese Science Bulletin, 1965:8: 705-713. (in Chinese)

[18] Chen W X, Wang ET. Chinese rhizobia. Science Press, ISBN: 9787030297891, 2011. (in Chinese)

[19] Fan Q S. Research and prospect of nitrogen fixing bacteria in soil in China. Acta Pedologica Sinica, 1963; 11(2): 220-228. (in Chinese)

[20] Meng Y, Xu F H, Meng Q Y, Gu W R. Current application status and prospect of microbiological fertilizer in China. Chinese Agricultural Science Bulletin, 2008: 24(6): 276-283. (in Chinese)

[21] Yang C D. Advances in and prospects of forest soil reaserch. Acta Pedologica Sinica, 2008; 45(5): 881-891. (in Chinese)

[22] Liu R C, Li F T Hao Z R Yang Z Y. The Development, research and popularization of biological potassium fertilizer (Silicate bacteria Inoculum). Scientia Agricultura Sinica, 1998; 31(1): 95-96. (in Chinese)

[23] Wang C F, Xu H L, Chang T T, Wang W N. Effects of compound microbial inoculant treated wastewater irrigation on soil nutrients and enzyme activities. Int J Agric \& Biol Eng, 2016; 9(6): 100-108.

[24] Sattar A, Naveed M, Ali M, Zahir Z A, Nadeem S M, Yaseen M, et al. Perspectives of potassium solubilizing microbes in sustainable food production system: A review. Applied Soil Ecology, 2019; 133: 146-159.

[25] Xue D, Huang X D, Song G D, Yang R X, Wang H M, Luo Q L. Screening and growth-promoting effect of phosphate-solubilizing fungi in the rhizosphere of Paeonia suffruticosa. Ecology and Environmental Sciences, 2018; 27(9): 1639-1645. (in Chinese)

[26] Majumder M S, Hossain M. Isolution and molecular characterization of phosphate solubilizing filamentous fungi from subtropical soils in Okinawa Applied Ecology and Environmental Research, 2019; 17: 9145-9157.

[27] Klaic R, Plotegher F, Ribeiro C, Zangirolami T C, Farinas C S. A fed-batch strategy integrated with mechanical activation improves the solubilization of phosphate rock by aspergillus niger. ACS Sustainable Chemistry \& Engineering, 2018; 6(9): 11326-11334.

[28] Ceci A, Pinzari F, Russo F, Maggi O, Persiani A M. Saprotrophic soil fungi to improve phosphorus solubilisation and release: In vitro abilities of several species. Ambio, 2018; 47(1): 30-40.

[29] Zhu M L, Gong L, Zhang L L. Soil enzyme activities and their relationships to environmental factors in a typical oasis in the upper reaches of the Tarim River. Environmental Science, 2015; 36(7): 2678-1685. (in Chinese)

[30] Lin X G. Principles and methods of soil microbiology research. Beijing: Higher Education Press, ISBN: 9787040284072, 2010. (in Chinese)

[31] Wu J S, Lin Q M, Huang Q Y, Xiao H A. Method and application of soil microbial biomass measurement. Beijing: China Meteorological Press, ISBN: 9787502941581, 2006. (in Chinese)

[32] Guan S Y. Soil enzymes and their research methods. Beijing: China Agricultrure Press, ISBN: 16144·3123, 1986. (in Chinese)

[33] Bao S D. Soil agro-chemistrical analysis. Beijing: China Agricultrure Press; ISBN: 9787109066441, 2008. (in Chinese)

[34] Tan Z J, Feng Y H, Liu F, Zhang Y Z, Zou Y B. Effects of rice-based cropping system and organic manure on microbes and enzyme activities in paddy soils derived from red earth. Chinese Journal of Eco-Agriculture, 
2004; 12(2): 121-123. (in Chinese)

[35] Wu N, Pan H-X, Qiu D, Zhang Y M. Feasibility of EPS-producing bacterial inoculation to speed up the sand aggregation in the Gurbantunggut Desert, Northwestern China. Journal of Basic Microbiology, 2014; 54(12) 1378-1386.

[36] Piekarska K, Trusz A, Szczesniak S. Bacteria and fungi in two air handling units with air recirculating module. Energy and Buildings, 2018; 178: 154-164.

[37] Wu Y, Hou L, Zhang J. Antagonistic effect of bacterial strains in complex microbial inoculants and the screening of their culture condition. Acta Agriculturae Zhejiangensis, 2016; 28(5): 820-827. (in Chinese)

[38] Schweigert M, Herrmann S, Miltner A, Fester T, Kaestner M. Fate of ectomycorrhizal fungal biomass in a soil bioreactor system and its contribution to soil organic matter formation. Soil Biology \& Biochemistry, 2015; 88: 120-127.

[39] Mahanta K, Jha D K, Rajkhowa D J, Manoj K. Microbial enrichment of vermicompost prepared from different plant biomasses and their effect on rice (Oryza sativa L.) growth and soil fertility. Biological Agriculture \& Horticulture, 2012; 28(4): 241-250.

[40] Ge T, Liu C, Yuan H, Zhao Z, Wu X, Zhu Z, et al. Tracking the photosynthesized carbon input into soil organic carbon pools in a rice soil fertilized with nitrogen. Plant and Soil, 2015; 392(1-2): 17-25.

[41] Cao Z, Li D, Han X. The fungal to bacterial ratio in soil food webs, and its measurement. Acta Ecologica Sinica, 2011; 31(16): 4741-4748. (in Chinese).

[42] Tian X, Li J, Wang C, Chu G, Wei C, Zheng Q, et al. Effects of continuous application of bio-organic fertilizer for three years on soil nutrients, microbial biomass and enzyme activity. Soils, 2014; 46(3): 481-488. (in Chinese)

[43] Guo R, Xia Z Z. Effect of continuous fertilization on biochemistry intensity of Lou soil. Journal of Anhui Agricultural Sciences, 2008; 36(27): 11859-11860, 11889. (in Chinese)

[44] Zhang W, Wang B. Study on phosphate-solubilizing activity and suitable conditions of a strain of bacillus mucilaginosus. Chinese Agricultural Science Bulletin, 2014; 30(21): 136-140. (in Chinese)

[45] Hou W, Yang L, Chen R, Zhang S. Effects of aspergillus niger phyA2 transgenic maize on utilization of organic phosphorus in soil. Acta Agronomica Sinica, 2013; 39(8): 1360-1365. (in Chinese)

[46] $\mathrm{Hu} \mathrm{J,} \mathrm{Yu} \mathrm{J} \mathrm{P,} \mathrm{Lian} \mathrm{B.} \mathrm{Capability} \mathrm{and} \mathrm{mechanism} \mathrm{of} \mathrm{potassium} \mathrm{releasing}$ from potassium-bearing minerals by aspergillus niger. Bulletin of Mineralogy Petrology and Geochemistry, 2011; 30(3): 277-285. (in Chinese)

[47] Biswas D R, Basak B B. Mobilization of potassium from waste mica by potassium-solubilizing bacteria (bacillus mucilaginosus) as influenced by temperature and incubation period under in vitro laboratory conditions. Agrochimica, 2014; 58(4): 309-320.

[48] Zhuang Z J, Du Y H, Zhu R Y, Zhang J H. Effects of silicate bacterium on biological character and nutrients accumulation of rice. China Rice, 2015; 21(6): 88-90. (in Chinese)

[49] Zhang X Q, Ren H J, Liu N, Zhang L Y, Zhou R. Changes in texture and retorting yield in oil shale during its bioleaching by bacillus mucilaginosus. Chemical Research in Chinese Universities, 2013; 29(2): 294-298.

[50] Meena V S, Maurya B R, Verma J P. Does a rhizospheric microorganism enhance $\mathrm{K}^{+}$availability in agricultural soils? Microbiological Research, 2014; 169(5-6): 337-347.

[51] Karavaiko G I, Krutsko V S, Mel'nikova E O, Avakian Z A, Ostroushko I I. Role of microorganisms in the destruction of spodumene. Mikrobiologiia, 1980; 49(3): 547-551.

[52] Gaind S. Effect of fungal consortium and animal manure amendments on phosphorus fractions of paddy-straw compost. International Biodeterioration \& Biodegradation, 2014; 94: 90-97.

[53] Abou-el-Seoud I I, Abdel-Megeed A. Impact of rock materials and biofertilizations on $\mathrm{P}$ and $\mathrm{K}$ availability for maize (Zea Maize) under calcareous soil conditions. Saudi Journal of Biological Sciences, 2012; 19(1): 55-63.

[54] Zhang L, Fan J, Niu W, Li T, Wu R, Jing Y, et al. Isolation of phosphate solubilizing fungus (aspergillus niger) from caragana rhizosphere and its potential for phosphate solubilization. Acta Ecologica Sinica, 2011; 31(24):7571-7578. (in Chinese)

[55] Kang S-M, Waqas M, Shahzad R, You Y-H, Asaf S, Khan MA, et al Isolation and characterization of a novel silicate-solubilizing bacterial strain Burkholderia eburnea CS4-2 that promotes growth of japonica rice (Oryza sativa L. cv. Dongjin). Soil Science and Plant Nutrition, 2017 63(3): 233-241.

[56] Ma J F, Yamaji N. Silicon uptake and accumulation in higher plants. Trends in Plant Science, 2006; 11(8): 392-397.

[57] Mitani N, Ma J F. Uptake system of silicon in different plant species. Journal of Experimental Botany, 2005; 56(414): 1255-1261.

[58] Liang Y, Si J, Römheld V. Silicon uptake and transport is an active process in Cucumis sativus. New Phytologist, 2005; 167(3): 797-804.

[59] Li X, Wu Z, Li W, Yan R, Li L, Li J, et al. Growth promoting effect of a transgenic bacillus mucilaginosus on tobacco planting. Applied Microbiology and Biotechnology, 2007; 74(5): 1120-1125.

[60] Han H S, Supanjani, Lee K D. Effect of co-inoculation with phosphate and potassium solubilizing bacteria on mineral uptake and growth of pepper and cucumber. Plant Soil and Environment, 2006; 52(3): $130-136$.

[61] $\mathrm{Hu} \mathrm{Z,} \mathrm{Wu} \mathrm{Y,} \mathrm{Mao} \mathrm{Z,} \mathrm{He} \mathrm{Y.} \mathrm{Isolation,} \mathrm{identification} \mathrm{and} \mathrm{biological}$ characterization of silicate bacteria. Acta Agriculturae Universitatis Jiangxiensis, 2013; 35(3): 609-614. (in Chinese)

[62] Wu J, Xie F, Fu T, Pan X, Shi Q. Effect of application of nitrogen combined with silicon on grain yield of double cropping rice and its nitrogen and silicon absorption. Acta Agriculturae Universitatis Jiangxiensis, 2017; 39(5): 843-850. (in Chinese)

[63] Pati S, Pal B, Badole S, Hazra G C, Mandal B. Effect of silicon fertilization on growth, yield, and nutrient uptake of rice. Communications in Soil Science and Plant Analysis, 2016; 47(3): 284-290.

[64] Ogut M, Er F, Neumann G. Increased proton extrusion of wheat roots by inoculation with phosphorus solubilising microorganims. Plant and Soil, 2011; 339(1-2): 285-297.

[65] Sun Y, Wang X, Wang Y, Pan W, Lu R, Ruan Z, et al. Soil available nutrients and rice yield with silicon and phosphorus fertilization. Journal of Zhejiang University, 2015; 32(4): 551-556. (in Chinese)

[66] Agostinho F B, Tubana B S, Martins M S, Datnoff L E. Effect of different silicon sources on yield and silicon uptake of rice grown under varying phosphorus rates. Plants-Basel, 2017; 6(3): 35-52. 